\title{
Advantages and Disadvantages of the Contemporary Relationship between China and Africa
}

\author{
Zalety i wady stosunków między Chinami a Afryką \\ w czasach współczesnych
}

\section{- Abstrakt •}

Chiński rząd rozpowszechnia chińską kulturę i filozofię w celu wsparcia swoich dążeń do osiągnięcia określonych celów politycznych i gospodarczych, a także działań w zakresie stosunków międzynarodowych. W konsekwencji afrykańscy studenci są zachęcani do nauki języka chińskiego, a studia kulturowe są współfinansowane przez ChRL. Jednak stosunki między Chinami a krajami afrykańskimi są kształtowane przez szersze uwarunkowania międzynarodowe, a nie działania podjęte przez same strony. W świetle takiej pozycji kontynentu afrykańskiego, wzrastająca siła gospodarcza Chin w tym regionie wydaje się nieuniknioną alternatywą dla kontynentu dryfującego w górę w kierunku podaży. Wraz z tym procesem pojawia się określony profil stosunków dwustronnych między Chinami i Afryką. Niniejszy artykuł ma na celu analizę wpływu Chin na kraje afrykańskie i głównych przyczyn leżących u podstaw ich stosunków.

Słowa kluczowe: Chiny; Afryka; stosunki dwustronne; handel; gospodarka

\section{- Abstract •}

The Chinese government is expanding Chinese culture and philosophy to support achievement of its political and economic goals as well as its international relations activities. In this context, African students are encouraged to learn Chinese and cultural studies are co-financed by the Chinese side. However, Relations between China and African countries are shaped by the international environment rather than the actions the parties themselves have undertaken. When this position of the African continent in mind, China's growing economic strength in this region seems an inevitable alternative for the continent. This gives a specific profile to the emerging bilateral relationship between the People's Republic and individual African states. This paper aims to analyze the impact of China on African countries and the underlying foundations of their relationship.

Keywords: China; Africa; bilateral relations; trade; economy 


\section{Introduction}

As over time China began its rise in importance, it started to exert an increasing influence on many countries, involving multiple local political leaders in the Chinese cooperative initiatives. This helped China progress as fast as we witnessed. The pace of China's economic growth averages $8 \%$ to $9 \%$ annually; the country is the fastest growing economy in the world in the last 30 years. A phenomenon that deserves particular attention is the rapid urbanization. Over the past three decades, about 300 million people have moved from rural areas to cities in China. In the coming years it is expected that urbanization will continue at a similar pace (Tyfield, 2017). Construction works are carried out on an unprecedented scale in the People's Republic of China (PRC) - currently, China uses half of all cement produced in the world, and a third of global steel volume. The number of high-rise buildings being built in China every year makes up almost half of the total number of such dwellings constructed around the world. In addition, across China upgrades of existing roads and construction of new highways are ongoing without pause. China continues its rapid development multiple sectors, boosting the overall economy (Liu, 2018).

In recent years, as a growing power PRC has gained status of a "partner" of many countries in the world, interested in cooperation in various spheres with this state. The truth is, there are disadvantages to such a relationship resulting largely from the political situation in the country. It is known that China is not a democracy and is often accused of human rights violations. China understands its growing power, wants to preserve what it has and expand it further - criticism and even sanctions, as after the events at the Tiananmen Square in Beijing, can be a significant impediment to this plan. To continue on its path to greatness, China is aware it needs support, if not from Europe then from other countries.

China found its partner and ally in the African region - a troubled continent with a high level of poverty. China invests a lot in Africa; both sides turn a blind eye to any wrongdoings and violations of human rights of the other party. Africa and China have found true partnership. But what are other reasons for cooperation between China and African states? What is the level of China's influence in Africa? Why does China gain from collaborating with the region's states? This paper aims to analyze the impact of China on African countries and the underlying foundations of their relationship. The paper is ordered as follows:

1. Introduction to the rising influence of China around the world.

2. Discussion of relations between China and Africa - split into analysis of both advantages and disadvantages of this relationship. 
The overall objectives of the paper are:

a) to evaluate the impact of cooperation with China on African countries,

b) to discuss the advantages and disadvantages of relationships China has with the states in Africa.

\section{Advantages of the Relationship between China and Africa}

There are advantages and disadvantages to every relationship of course - for the purpose of this paper, we'll start with the advantages of the China-Africa cooperation. The key reason that likely forms the basis of this partnership is that the whole of Europe and many other countries see Africa as a source of problems, a territory suffering from truly painful levels of poverty, one that needs humanitarian assistance, food transports, privileged loans to be extended to various states and other forms of support. Europe and the US continued to send humanitarian aid, while China instead invested in construction of industrial enterprises, development of mutual trade and local agriculture. China's economic policy proved to be more effective since it made African states dependent on investments from the PRC. China sees this as a continent offering real opportunities (Dreher, 2018). Africa is rich in oil, copper, cobalt and iron ore. It is a market for Chinese manufacturers and construction companies. China invests a lot in Africa - factories built with Chinese money open one by one in Ethiopia, Rwanda and Nigeria; the first automotive production plant will soon begin operating in Cameroon. In Kenya, China financed and helped build the largest infrastructure project in the last 50 years - the railway from the capital city of Nairobi to the port city of Mombasa. And in stores in Nairobi itself, no one is surprised to see an entire alley with Chinese-made products destined for the local Chinese diaspora. In addition, most students from Africa study in China through scholarships paid by the Chinese government, and thousands of African officials and politicians regularly visit China - both for official and unofficial purposes. Moreover, in the small African country of Djibouti, China built its first foreign military base (Zhao, 2017). Imports and exports between the PRC and African states also increased. China imports currently more mineral products from Africa than the US. "The deepening relationship between China and the continent has led to the formation of the Forum on China-Africa Cooperation (FOCAC). The first ministerial conference of FOCAC was held in 2000 with the most recent one held this past July in Beijing. So, you see that the country has become Africa's largest trading partner" (Bhagawati, 2018). 
But why does China continue to work so hard at strengthening its relationship with Africa? The above reasons are the economic rationale that helps countries reach their development goals. But, of course, there is also a political reason for this cooperation. Obviously, China wants to expand its influence and Africa is precisely the territory on which China focuses its efforts - for China, it is beneficial as Africa is rich in natural resources such as oil and others minerals. In addition, as indicated above, China is gradually establishing its military forces there. China wants to consolidate and strengthen its influence; thus it invests so much in various forms of cooperation with Africa. African states, in turn, are loyally supportive. For example, after the Tiananmen Square protests were suppressed, African countries preferred to refrain from expressing an opinion - China's influence in Africa is sufficient to ensure support on its part and stop criticism (Ayodele, Sotola, 2014).

Many believe that China is in a sense colonizing or occupying Africa, and seeks only profits for itself - others refute this opinion. While it is true that China benefits from the collaboration, there are also benefits to Africa itself: the funds invested are so large, the local state economies can start to gradually grow. Consequently, there are more jobs and over time the level of poverty will decline. And cooperation with such a rapidly developing and powerful country as China grants African states also a more prestigious status in the world arena. Of course, this does not improve Africa's image to an unlimited degree - if only because Europe has a different opinion on the situation in Africa. Europe, like America, regards Africa as a territory of instability, and therefore does not see the opinions of its leaders as equally worth listening to. Nevertheless, China gives African states a chance to improve their status somewhat (Ademola et al., 2016).

\section{Disadvantages of the Relationship between China and Africa}

Apart from these benefits, there are also drawbacks to the partnership - for both sides. As already mentioned above, many people complain that China has in fact economically occupied the African countries. In addition, there is also much talk of exploiting the labor force, disrespecting local workers, and so on. Chinese corporations also do not monitor compliance with environmental norms, participate in corruption schemes and allow for multiple violations of the rights of African workers. All in all, they ready to increase profits by any means, while cooperating with authoritarian regimes and accepting lack of democracy and human rights breaches (Cornelissen et al., 2015). 
In addition, while indeed thanks to numerous Chinese factories new workplaces are being created across Africa, one should not hold any illusions as to for whom they are intended - over the previous decade, about a million Chinese people have moved to Africa and they occupy the lion's share of the newly created positions. Furthermore, the cheap Chinese imports that have poured into the continent proved to be an unbeatable competitor for local small businesses, which, even without this challenger were in a difficult situation. As a result, according to experts from the African Globe, the African economy lost approx. 75000 jobs due to growing Chinese penetration (Adem, 2016).

Thirdly, in the West the Chinese activities in Africa have long been described as exploitative, sometimes talk about their neo-colonial nature can be heard as well. However, even in the African countries themselves, people comment that China takes raw materials from Africa and sells what it produces on their basis elsewhere, without sharing the know-how and technology. When talking about exploitation, it should be made clear that while Chinese labor is seen as cheap, labor in Ethiopia is even cheaper. If a Chinese worker costs 500 dollars a month, then in Ethiopia the cost for similar position occupied by a local worker is USD 50. Therefore, Chinese firms are trying to employ Ethiopians for lower positions. Not only is the labor cheap, but the people working for the investing firms are not treated with respect. They work in exchange for small salaries and work very hard - this applies to children as well, as with the very low standard of living prevalent everyone is ready to work to improve their lot in life. Thus in fact Chinese companies are making profit often on exploitation of child labor. Tensions between China and Africa centered on this issue are growing (Pigato, Tang, 2015).

For China, its image in Africa is very important, so the People's Republic tries to show improved conditions of work and to refute these rumors and conversations in every possible way. In this exchange, the Chinese are using African people living in China as their spokes-persons since their personal experiences are overall positive, with better living conditions, especially when it comes to students who receive scholarships sponsored by the PRC. Also, in order to improve the relations with African states, China has decided to create a strategy for improving quality of life in African countries, especially its southern part. This strategy contains a set of specific medical, agricultural and infrastructure projects, the implementation of which - with the participation of Chinese capital - will be starting soon. The plan is ambitious enough that the share of African countries in total aid distributed by the Chinese has increased compared to the past years - with the new strategy, support for Africa accounts for 50 percent of it (Hodzi, 2018). 


\section{Conclusion}

In conclusion, the African-Chinese relationship is a mutually beneficial one. On the one hand, China does indeed invest a lot in Africa, many China-funded firms and factories operate on the continent, creating jobs for people living there. Also, Chinese citizens live in Africa while the African expat community in China grows, strengthened in numbers by students receiving a training scholarship financed by the People's Republic. This is a very big plus for young people, in particular young people from Africa where many do not have access to normal educational infrastructure - thanks to such scholarships they have the opportunity to study abroad, get higher education and take up prestigious work in the future. They would be equally able to get a job in China as in Europe. Due to its influence on the countries of Africa, China expands its influence as a whole. Also, thanks to an alliance with China, Africa can also increase its importance in the international arena. By investing in many sectors of African economies and creating branches of Chinese firms in Africa, the Chinese partner creates a lot of jobs that can give a boost to the local economy.

The answer to the question of why China continues to intensify its relations with a relatively underdeveloped region like Africa is pretty easy - the reason are, of course, the natural resources available in Africa, which are attractive not only to China. Secondary reason is the chance to boost its political influence and be able to count on support of African countries in the global arena.

One cannot be blind that cheap labor is used in such Chinese investments. In addition, with the advent of Chinese firms, many Chinese citizens migrated to Africa, which created great competition among the local population for the jobs created as a lot of positions were taken by the Chinese nationals. Interestingly, China's increased influence in Africa created a problem of job competition.

Of course, there are both advantages and disadvantages to the relationship between China and Africa. For Africa, as China's influence is growing and will continue to grow, the greatest benefit is a chance to raise the standard of living of the local population and improve the standing of a given country in the international arena. 


\section{References:}

Adem, S. (2016). (ed.). China's Diplomacy in Eastern and Southern Africa (pp. 27-87). London: Routledge.

Ademola, O.T., Bankole, A.S., Adewuyi, A.O. (2016). China-Africa Trade Relations: Insights from AERC Scoping Studies. In: The Power of the Chinese Dragon (pp. 69-97). London: Palgrave Macmillan.

Ayodele, T., Sotola, O. (2014). China in Africa: An Evaluation of Chinese Investment. Initiative for Public Policy Analysis, 1-20.

Bhagawati, J. (2018). China's Growing Influence in Africa: Lessons for India (pp. 2-6). Retrieved from: http://www.maritimeindia.org/View\%20Profile/636554768556884329. pdf.

Cornelissen, S., Cheru, F., Shaw, T. (2015). (eds.). Africa and International Relations in the $21^{\text {st }}$ Century (pp. 21-51). Basingstoke: Palgrave Macmillan.

Dreher, A., Fuchs, A., Parks, B., Strange, A.M., Tierney, M.J. (2018). Apples and Dragon Fruits: The Determinants of Aid and Other Forms of State Financing from China to Africa. International Studies Quarterly, 62(1), 182-194.

Hodzi, O. (2018). China and Africa: Economic Growth and a Non-Transformative Political Elite. Journal of Contemporary African Studies, 36(2), 191-206.

Liu, T.T.T. (2018). The Rise of China. Education About ASIA, 23(1), 5-7.

Pigato, M., Tang, W. (2015). China and Africa: Expanding Economic Ties in an Evolving Global Context, (Vol. 2, pp. 5-20). Washington DC: World Bank.

Tyfield, D. (2017). Liberalism 2.0 and the Rise of China: Global Crisis, Innovation and Urban Mobility. New York: Routledge.

Zhao, S. (2017). (ed.). China in Africa: Strategic Motives and Economic Interests. New York: Routledge. 